\title{
In vitro study of bond strength at the resin/brackets interface in first premolars using orthodontics resins and restorative resins
}

\author{
Estudo in vitro da resistência da união na interface \\ resina/bráquete em pré-molares inferiores usando resinas \\ ortodônticas e resinas de restauração
}

\section{Estudio in vitro de resistencia a la unión en la interfaz de resina/bracket en premolares inferiores utilizando resinas de ortodoncia y resinas de restauración}

\author{
Ghenna Eliza Chamorro Arias (iD \\ Jenny Edith Collantes Acuña iD \\ Luiz Eduardo Alessio Junior (iD \\ Emerson Flamarion da Cruz iD \\ Endereço para correspondência: \\ Luiz Eduardo Alessio Junior \\ Rua Henrique Savi, 3-62 \\ 17012-205 - Bauru - São Paulo - Brasil \\ E-mail: lui.alessio@gmail.com
}

Recebido: 13.08 .2020

Modificado: 28.08.2020

Aceito: 11.09.2020

\begin{abstract}
The shear bon strength (SBS) to brackets to the teeth, is necessary strength to resist orthodontic movements, mastication forces induced by food and other forces. The retention mechanism of the bracket base, the preparation of dental and the adhesive material affecting the adhesion between the metal brackets and tooth enamel. Therefore, the purpose of this study is to investigate different systems adhesion; Z100 (3M Unitek, USA), Transbond XT (3M Unitek, USA) and Trulock (RMO, USA) on the shear bond strength of brackets to the enamel. 135 first human premolars, mounted on an acrylic base, were divided into 3 groups of 45 pieces each. They are prepared following the same protocol and a same type of metal brackets bonded, light activated for $40 \mathrm{~s}$, and stored. SBS was performed in an Instron at crosshead speed of $2.0 \mathrm{~mm} / \mathrm{min}$. Data were submitted to the Student $t$ test. The Adhesive Remaining Index (ARI) was evaluated. The is no statistical difference between 3 groups. The ARI showed a predominance of scores 2 and 3 for all groups. It is possible conclude that Z100 restoration resin can be used to the adhesion of the orthodontic brackets.
\end{abstract}

KEYWORDS: Dental materials. Orthodontics. Resins.

\section{RESUMO}

A resistência ao cisalhamento (SBS) dos bráquetes aos dentes é a força necessária para resistir aos movimentos ortodônticos, forças mastigatórias induzidas por alimentos e outras forças. O mecanismo de retenção da base do bráquetes, a preparação do material dentário e adesivo afetam a adesão entre os bráquetes metálicos e o esmalte do dente. Portanto, o objetivo deste estudo 
In vitro study of bond strength at the resin/brackets interface in first premolars using orthodontics resins and restorative resins

é investigar a adesão de diferentes sistemas; Z100 (3M Unitek, EUA), Transbond XT (3M Unitek, EUA) e Trulock (RMO, EUA) na resistência ao cisalhamento dos bráquetes ao esmalte. 135 primeiros pré-molares humanos, montados em uma base de acrílico, foram divididos em 3 grupos de 45 peças cada. Eles são preparados seguindo o mesmo protocolo e o mesmo tipo de suportes de metal ligados, ativados por luz por $40 \mathrm{se}$ armazenados. O SBS foi realizado em um Instron na velocidade da cruzeta de $2.0 \mathrm{~mm} / \mathrm{min}$. Os dados foram submetidos ao teste t de Student. O Índice Adesivo Remanescente (ARI) foi avaliado. Não há

diferença estatística em entre os três grupos. O ARI mostrou predominância dos escores 2 e 3 para todos os grupos. É possível concluir que a resina de restauração Z100 pode ser utilizada para a adesão dos bráquetes ortodônticos.

PALAVRAS-CHAVE: Materiais dentários. Ortodontia. Resinas.

\section{RESUMEN}

La resistencia al cizallamiento (SBS) de braquets a dientes es la fuerza necesaria para resistir los movimientos de ortodoncia, las fuerzas masticatorias inducidas por alimentos y otras fuerzas. El mecanismo de retención de la base de braquets, la preparación del material dental y adhesivo afectan el soporte entre los braquetes metálicos y el esmalte dental. Por lo tanto, el objetivo de este estudio es investigar el apoyo de diferentes sistemas; Z100 (3M Unitek, USA), Transbond XT (3M Unitek, USA) y Trulock (RMO, EUA) en la resistencia a la cizalla de los soportes para el esmalte. 135 primeros premolares humanos, montados sobre una base acrílica, se dividieron en 3 grupos de 45 piezas cada uno. Se preparan siguiendo el mismo protocolo y tipo de soportes metálicos conectados, activados por la luz durante $40 \mathrm{~s}$ y almacenados. El SBS se realizó en un Instron a una velocidad de cruz de $2.0 \mathrm{~mm} / \mathrm{min}$. Los datos fueron enviados a la prueba t del estudiante. Se evaluó el índice adhesivo restante (ARI). No hay diferencia estadística entre los tres grupos. La ARI mostró predominio de las puntuaciones 2 y 3 para todos los grupos. Es posible concluir que la resina de restauración Z100 se puede utilizar para la adhesión de braquetes de ortodoncia.

PALABRAS CLAVE: Materiales dentales. Ortodoncia. Resinas. 


\section{INTRODUCTION}

The main concern for the orthodontist is the adhesion of the brackets to tooth enamel, so that union, obtained support the forces and to resist orthodontic movements, chewing, food-induced forces and other forces supported by braces ${ }^{1}$.

The adhesion strength can be measured through tensile forces, compression, shear and torsion, to determine the level of adhesion failure, especially in the resin interface/enamel/bracket, quantifying this way which is the maximum force required for the release occurs. Hear bond strength (SBS) test is done by exerting shear forces on the brackets until the fault, to further quantify the force that were displaced ${ }^{2}$. As discussed ${ }^{3}$, many other studies report that the bond strength range of to $10 \mathrm{MPa}$ is adequate to stand clinical situations with no adhesion failure.

Orthodontic treatment an ideal adhesive should have adequate bond strength while maintaining unblemished enamel after debonding as well as the possibility of being removed without difficulty ${ }^{2}$.

There are three well known factors affecting the adhesion between the metal brackets and tooth enamel, these are the retention mechanism based on the bracket, the adhesive material and the preparation of the tooth surface, thus for proper adhesion is necessary optimum type brackets, adhesive materials high quality and especially, the control of the bonding technique and cementation efficient ${ }^{4}$.

In the case of the adhesive material is the restauration composite resin, which generally consists of a modified epoxy resin. However, the continued technological development has enabled optimization of this type of resin, resulting in new specific formulations for orthodontic treatments, composed of monomers of methylmethacrylate and increasingly finer particles. The main difference between the various types of materials is photopolymerizable composite resin containing a matrix of inorganic reinforcement ${ }^{5}$. In orthodontic practice, lowviscosity adhesive resins are used to bond the orthodontic brackets. Bond strengths in low-viscosity adhesives have been shown in some reports no significant differences exist between these two types of adhesive ${ }^{6}$.

To date, only one study in the field of restorative dentistry has evaluated the bond strength of composite resin to orthodontic brackets. Therefore, the purpose of this study is to investigate different systems adhesion; Z100 (3M Unitek, USA), Transbond XT (3M Unitek, USA) and Trulock (RMO, USA) on the shear bond strength of brackets to the enamel. After the tests, the adhesive remnant (ARI score) was analyzed.

\section{MATERIAL AND METHODS}

\section{Preparation of the Samples}

This research is in vitro study where 135 premolars with intact buccal surfaces, which were freshly extracted for orthodontic purposes and donated, and immediately stored in a saline solution. The teeth selected for this study were healthy and free of any flaws that might impair adhesion. The teeth were vertically mounted in self-cured acrylic resin cylinders within $2 \times 2 \mathrm{~cm}$ PVC rings with the buccal surface aligned perpendicular to the mold and were randomly divided into three groups.

The premolars, were divided into three major groups based on the composite: Group $1(n=45)$ - composite for use in oral rehabilitation (Z100 - 3M Unitek, Monrovia, CA, USA); Group $2(\mathrm{n}=45)$ - orthodontic composite (Transbond XT - 3M Unitek, Monrovia, CA, USA); Group $3(n=45)$ - orthodontic composite (Trulock-RMO, USA).

Prophylaxis and collage of brackets on the buccal surface of each piece was conducted following the following protocol: the teeth were cleaned and polished using a rubber cap and non-fluoridated pumice for 30 seconds. Completely dry, all the teeth were acid etched for 15 seconds with $35 \%$ phosphoric acid gel (Ultra-Etch Ultradent), and thoroughly washed for 40 seconds with water and dried with an air supply free of oil and water.

The adhesive resin was applied to the base of premolar stainless-steel brackets (Edgewise 0,022", Morelli, Sorocaba, SP, Brazil), and then the bracket was pressed firmly onto the prepared enamel surface, at the center of the clinical crown. Excess adhesive was removed from bracket margin using a scaler. The light-curing was applied for $40 \mathrm{~s}$ (20s from each side occlusal and cervical) at distance of 1-2 $\mathrm{mm}$ of light tip from bracket margins using a portable light curing device (Optilux 400, Demetron, USA).

\section{Resistance Test}

Bracket bond strength was tested using an Instron Universal Testing machine (DL500, EMIC, Brazil), at Laboratory of the Department of Mechanical Engineering, Escuela Polytechnic Nacional, Quito, Ecuador. In such the test tool was precisely positioned in the interface between bracket and enamel surface and applying shear force at an angle of $90^{\circ}$, creating shear force at a crosshead speed of 15 $\mathrm{mm}$, (interval shift length by the movable upper part of the machine, with a maximum of $10 \mathrm{~mm}$, speed of the working arm of the machine of $2 \mathrm{~mm} / \mathrm{min}$ ) with a load cell range of 30 Newtons $(\mathrm{N})$, until failure. The debonding force was recorded in Newton and converted into $\mathrm{MPa}$.

After debonding, the enamel surfaces were viewed under a stereomicroscope to check adhesive remnants on 
the buccal surface of the teeth, by a blinded operator according to the adhesive remnant index (ARI) categories as follows: 0 - No composite remained; 1 - Less $50 \%$ of the composite remained; 2 - More than $50 \%$ of the composite remained and 3 - The whole composite remained including the impression of the bracket base?

\section{Statistical Analysis}

The means, standard deviations, and ranges of the SBS and adhesive thickness were calculated for each group. As the data for bond stress demonstrated a normal distribution and a t-test for independent samples was used to compare bond strength values between adhesives at $95 \%$ confidence level. The Chi Square test was used to evaluate the adhesive remnant index. For all statistical tests, the level of significance was set at 0.05 .

\section{RESULTS}

The mean of SBS of 135 samples in three groups was $14.10 \pm 5.6 \mathrm{MPa}$. The mean of confidence intervals of $95 \%$ to the Group 2 presented the highest amplitude $3.71 \mathrm{MPa}$, the lowest amplitude is reported by the shear resistance of the Group 1 2.79 MPa (Table 1).

Table 1 - Mean, range and 95\% confidence Interval for mean of shear bond strength in groups.

\begin{tabular}{cccc}
\hline Groups & Mean (MPa) & Range (MPa) & $95 \% \mathrm{Cl}$ \\
\hline Group 1 $(\mathrm{N}=45)$ & $13.80^{\mathrm{a}^{*}}$ & $7.29-21.37$ & 2.79 \\
\hline Group 2 $(\mathrm{N}=45)$ & $15.33^{\mathrm{a}^{*}}$ & $7.45-25.98$ & 3.71 \\
\hline Group 3 $(\mathrm{N}=45)$ & $13.29^{\mathrm{a}^{*}}$ & $7.53-26.31$ & 3.45 \\
\hline Total $(\mathrm{N}=135)$ & $14.1 \pm 5.6$ & & \\
\hline${ }^{*}$ Same letter indicates statistical similarity $(\mathrm{P}>0.05)$. &
\end{tabular}

The Table 1 show the shear bond strength to Group 1 mean 13.80 MPa (range: $7.29-21.37 \mathrm{MPa}$ ), the highest value is reported to the Group 2 mean $15.33 \mathrm{MPa}$ (range $7.45-25.98 \mathrm{MPa}$ ), and the lowest value is found in the Group 3 mean 13.29 MPa (range: 7.53 - 26.31 MPa). The maximum value of observations is $26.31 \mathrm{MPa}$ present in Group 3 and the minimum in Group 1 with $7.29 \mathrm{MPa}$ (Table 1). The comparison using $t$ test for independent samples detected no significant differences ( $p>0.05)$.

The results of adhesive remnant index (ARI) scores are shown in Table 2, no statistical significance in the sample, because the calculated $\mathrm{p}$-value is greater than $0.05(\mathrm{p}=0.297)$.
Table 2 - Frequency of the remaining adhesion index.

\begin{tabular}{c|c|c|c|c|c}
\hline Composite & 0 & 1 & 2 & 3 & Total \\
\hline Group 1 & 0 & 42 & 3 & 0 & 45 \\
\hline Group 2 & 0 & 39 & 6 & 0 & 45 \\
\hline Group 3 & 0 & 42 & 3 & 0 & 45 \\
\hline Total & 0 & 123 & 12 & 0 & 135 \\
\hline$p$-valor & \multicolumn{7}{|c}{0.297} \\
\hline
\end{tabular}

\section{DISCUSSION}

In the review of literature found only one $s \mathrm{Ady}^{8}$ compare the SBR of Transbond XT (3M Unitek, USA) with Z100 (3M Unitek, USA) and mixtures of both resins, evidenced that Transbond XT (3M Unitek, USA) was higher than Z100 (3M Unitek, USA). Z100 (3M Unitek, USA) resin is a product designed for direct and indirect restorations, of microhybrid type, composed of TEGDMA and BIS-GMA, together with zirconium filler particles, with a silane treatment, the latter element is the binding agent ${ }^{9}$. Based on the results of the SBS in the 3 groups, it is evident that Transbond XT resin reports the highest value 15.33 MPa, followed by the resin Z100 with $13.80 \mathrm{MPa}$ and the lowest value is reported in the Trulock resin which is 13.29 MPa. Therefore, the three adhesive resins studied are clinically acceptable for presenting values greater than 8 $\mathrm{MPa}$. It is possible conclude that Z100 resin restoration can be used to the adhesion of the brackets.

The SBS mean of Transbond XT resin reported in the literature between $40.76 \times 12.63 \mathrm{MPa}$, the values are high, and this resistance is clinically accepted. These values exceed by more than $25.43 \mathrm{MPa}$ the findings identified in this investigation (Group $2=15.33 \mathrm{MPa}$ ). The difference is the base of the bracket used and therefore the area, where the force was applied, the greater the area increases the $\mathrm{SBS}^{10}$.

The area of the base of the bracket, the type of design, are elements that influence the adhesion of the orthodontic appliance to the enamel and can influence the SBS. To make a successful orthodontic treatment, it is important to ensure an adequate adhesion force, without exceeding the limits of adhesion, because it would damage the enamel, at the time of removal of the bracket after the treatment is finished ${ }^{10}$. The ideal adhesion force required is not the maximum bonding force, it must be sufficient during the orthodontic treatment to keep the braces and at the same time minimum bonding force to allow removal of the support ${ }^{11}$. Therefore, the non-statistical difference in SBS between the groups, we can affirm the brackets bonded with Z-100 resin, will not cause damage to the surface of the dental enamel. 
Demonstrated that there were no significant differences between the SBS of Transbond XT $(9.46 \times 2.86$ $\mathrm{MPa})$, Transbond Plus SEP $(8.71 \times 2.71 \mathrm{MPa})$ and other systems $^{12}$. The authors affirm that Transbond XT has a composition of quartz treated with silane, bisphenol A, diglicidil ether, dimethylalate, bis (2-hydroxyethyl ether), dichlorodimethyl silane, silica reaction products, designed for the adhesion of orthodontic appliances, for ease to use, rapid adhesion, immediate adhesion force that decreases the time of the patient's chair, which would facilitate maintenance and avoid adhesion failures due to contamination $^{13}$. Z100 is not a specific resin for orthodontics, therefore, there will be greater manipulation and greater contamination during bonding of brackets.

Transbond $\mathrm{XT}^{14}$, resin had better adhesion when using different means of tooth conditioning (alcohol and sodium hypochlorite at 2\%), compared to the SBS of Trulock resin. In this study there no difference between the groups (Table 1).

The residual resin on the surface of the tooth or the base support is an important factor for orthodontists to select orthodontic adhesive. Although differences in adhesive remaining scores reflect the bonding strength, the adhesive systems exhibiting less residual resin are preferable because being easier and safer to clean after debonding procedures. As resin penetrate the enamel surfaces, they can have irreversible effects on the surfaces of the enamel after removing the braces ${ }^{15}$.

Transbond XT exhibited greater than $50 \%$ of remaining adhesive ( 2 index scale) to the ename ${ }^{16}$, this is attributed to the acid etching allow greater penetration of the resin, facilitating a better mechanical bonding between the composite and the enamel. In addition ${ }^{10}$. According to the remaining adhesion index (ARI), the three types of resins studied have the same proportions with less than 50\% remaining adhesive, so no significant difference is established between them $(\mathrm{p}>0.05)$.

\section{CONCLUSION}

The results show that there is no significant difference between the resins to the shear test at the resin/enamel/bracket interface. However, resins are clinically acceptable because they have values higher than $8 \mathrm{Mpa}$.

According to the Remaining Resin Index, the three types of resins studied have the same proportions with less than $50 \%$ residual resin, so no significant difference.

\section{REFERENCES}

1. Ferreto 1, Cáceres H, Chan J. Comparación de la fuerza de adhesión de brackets a esmalte dental con un sistema exclusivo para ortodoncia y un sistema restaurativo. Rev Cient Odontol. 2016;12:8-14.

2. Aguilar A, Ferreto I, Rodríguez L, Cáceres Z. Fuerza de adhesión de un sistema adhesivo de uso de ortodoncia. Odovtos - Int J Dent Sci. $2013 ; 15: 7-12$

3. Pickett KL, Sadowsky PL, Jacobson A, Lacefield W. Orthodontic in vivo bond strength: comparison with in vitro results. Angle Orthod. 2001;71(2):141-8.

4. Guerra A, Villacrés M. Comparación in vitro de la fuerza de adhesión sobre esmalte de brackets Clarity estándar (Transbond XT 3M) con los brackets Clarity APC Plus (3M), mediante una prueba de cizallamiento. OdontoInvestig. 2015;1(1):7-13.

5. Caballero A, Bincos C, Fernández J, Rivera J, Tanaka E. Comparación de la fuerza de adhesión y el tipo de falla entre dos cementos de resina para ortodoncia. Univ Odontol. 2011;30(65):31-9.

6. Tecco S, Traini T, Caputi S, Festa F, de Luca V, D'AttilioM. A new one-step dental flowable composite for orthodontic use: an in vitro bond strength study. Angle Orthod, 2005;75(4):672-7.

7. Artun J, Bergland S. Clinical trials with crystal growth conditioning as an alternative to acid-etch enamel pretreatment. Am J Orthod. 1984;85(4):333-40.

8. Romano F, Tavares S, Nouer D, Consanid S, Araújo B, Beatriz M. Shear bond strength of metallic orthodontic brackets bonded to enamel prepared with self-etching primer. Angle Orthod. 2005;75(5):849-53.

9. Moreno F. Colorimetría de cuerpos de prueba y restauraciones en resina compuesta sometidos a altas temperaturas con fines forenses: estandarización de un método in vitro. Colomb Forense, 2016;3(2):7-13.

10. Souza F, Oliveira D, Silva K, Schwarzbach M, Werner S, Santos K. In vitro analysis of shear bond strength and adhesive remnant index of different metal brackets. Dental Press J Orthod. 2016;21(6):67-73.

11. Lee JY, Ahn J, An SI, Park Jw. Comparison of bond strengths of ceramic brackets bonded to zirconia surfaces using different zirconia primers and a universal adhesive. Restor Dent Endod. 2018;43(1):e7-11.

12. Hammad S, El-Wassefy N, Maher A, Fawakerji S. Effect of nanotechnology in self-etch bonding systems on the shear bond strength of stainless steel orthodontic brackets. Dental Press J Orthod. 2017;22(1):47-56.

13. Maêda A, Romano F, Bortolazzo A. Shear bond strength of Concise and Transbond XT composites with and without bonding agent. Dental Press J Orthod. 2011;16(6):63-8.

14. Troya A. Comparación in vitro de las fuerza adhesiva entre dos resinas usadas para la cementación de brackets en el tratamiento de ortodoncia [monograph]. Quito: Universidad de las Américas; 2017.

15. Alper A, Yazicioglu S, Arici N, Akdeniz B, Mirat N, Arici S. Assessment of the confidence of the adhesive remnant index score with different methods. Turkish J Orthod. 2014;26(4):149-53.

16. Schauseil M, Blöcher S, Hellak A, Roggendorf M, Stein S, Korbmacher-Steiner H. Shear bond strength and debonding characteristics of a new premixed self-etching with a reference totaletch adhesive. Head Face Med 2016;12(1):23-37. 